University of Nebraska - Lincoln

DigitalCommons@University of Nebraska - Lincoln

West Central Research and Extension Center, North Platte

Agricultural Research Division of IANR

2004

Natural Product Herbicides for Control of Annual Vegetation Along Roadsides

Stephen L. Young

University of Nebraska - Lincoln, steve.young@usu.edu

Follow this and additional works at: https://digitalcommons.unl.edu/westcentresext

Part of the Agriculture Commons

Young, Stephen L., "Natural Product Herbicides for Control of Annual Vegetation Along Roadsides" (2004). West Central Research and Extension Center, North Platte. 4.

https://digitalcommons.unl.edu/westcentresext/4

This Article is brought to you for free and open access by the Agricultural Research Division of IANR at DigitalCommons@University of Nebraska - Lincoln. It has been accepted for inclusion in West Central Research and Extension Center, North Platte by an authorized administrator of DigitalCommons@University of Nebraska - Lincoln. 


\title{
Natural Product Herbicides for Control of Annual Vegetation Along Roadsides ${ }^{1}$
}

\author{
STEVE L. YOUNG ${ }^{2}$
}

\begin{abstract}
Natural product herbicides for vegetation control are being considered as alternatives to synthetic herbicides by many public agencies. Studies were conducted along roadsides at the Hopland Research and Extension Center (HREC) in 2001 and 2002 and on California State Route 29 (SR29) in 2002 to evaluate acetic acid, pine oil, and plant essentials compared with glyphosate for control of herbaceous vegetation. In 2001, annual grass control after a single application of pine oil at HREC was $40 \%$ or less effective, whereas acetic acid was at least $79 \%$ effective. A second application of pine oil or acetic acid did not control regrowth or new plants. In 2002, plant essentials was the most effective $(>80 \%)$ natural product at HREC for control of annual grasses, except slender oat. Pine oil often provided similar control of slender oat as plant essentials (71 and 69\%, respectively). At SR29, five applications of acetic acid provided $83 \%$ or better control of slender oat, hare barley, medusahead, and broadleaf filaree. Plant essentials and pine oil controlled hairy vetch, broadleaf filaree, and hare barley at least $83 \%$, but yellow starthistle, soft chess, buckhorn plantain, and medusahead control never exceeded $85 \%$. Glyphosate controlled all vegetation in these experiments with one or two applications. The cost of one or more applications of the natural products was greater than 10 times the cost of using one or two applications of glyphosate. Natural products were neither efficaciously nor economically comparable with glyphosate for control of annual roadside vegetation. Nomenclature: Acetic acid; glyphosate; pine oil; pine oil terpenes; plant essentials; 2-methoxy-4(2-propenyl)phenol 2-phenethyl propionate; broadleaf filaree, Erodium botrys (Cav.) Bertol. \# ${ }^{3}$ EROBO; buckhorn plantain, Plantago lanceolata L. \# PLALA; hairy vetch, Vicia villosa Roth \# VICVI; hare barley, Hordeum leporinum L. \# HORLE; medusahead, Taeniatherum caput-medusae (L.) Nevski \# ELYCM; slender oat, Avena barbata Pott ex Link \# AVEBA; soft chess, Bromus mollis L. \# BROMO; yellow starthistle, Centaurea solstitialis L. \# CENSO.
\end{abstract}

Additional index words: Chemical weed control, economics, integrated roadside vegetation management.

Abbreviations: DAT, days after treatment; EPA, Environmental Protection Agency; FIFRA, Federal Insecticide, Fungicide and Rodenticide Act; HREC, Hopland Research and Extension Center; SR29, California State Route 29.

\section{INTRODUCTION}

The focus of an integrated roadside vegetation management program is to use a variety of methods to control or maintain vegetation. The selected method must be effective in terms of both cost and control. Roadside vegetation managers rely heavily on mechanical, cultural, and chemical methods to control weeds because these methods are quick, efficient, and effective in reducing plant biomass to ensure traffic safety. The chemical methods, in particular, have raised public concern and

\footnotetext{
${ }^{1}$ Received for publication April 3, 2003, in revised form October 18, 2003.

${ }^{2}$ Staff Research Associate, University of California Hopland Research and Extension Center, Hopland, CA 95449. Corresponding author's E-mail: slyoung@ucdavis.edu.

${ }^{3}$ Letters following this symbol are a WSSA-approved computer code from Composite List of Weeds, Revised 1989. Available only on computer disk from WSSA, 810 East 10th Street, Lawrence, KS 66044-8897.
}

debate, especially because vegetation management is increasingly in the public eye (i.e., roadsides, parks, and recreation areas). This phenomenon also is increasing in the agricultural sector with the rise of organic farming and the sale of "residue-free" produce at local grocery stores. Instead of eliminating the use of chemicals for vegetation control in public places, some public departments (i.e., departments of transportation) are researching alternative chemicals (i.e., natural product herbicides) that are perceived by the public as being less toxic. Natural product herbicides, hereafter referred to as natural products, are composed of active ingredients that occur naturally (i.e., acids, oils, and soaps).

Within the United States, natural products, as opposed to synthetic herbicides, have not been used to control vegetation, particularly along roadsides, because there is 
almost no scientific evidence that they work or are cost effective. Only a small amount of research has been conducted demonstrating the efficacy of natural products (Bingaman and Christians 1995; Bingaman et al. 2000; Vurro and Gressel 2001). Natural products are being considered by specialists in all fields relating to vegetation control to find additional tools for use in areas of greater public concern.

Most natural products destroy plant tissue through contact action. Natural products are fast acting and in some instances require less than half an hour before the plant begins to wilt or turn color. ${ }^{4}$ The amount of damage to the plant depends on application timing and number and natural product concentration and coverage (Neal 1998). Rates of natural products for weed control are sometimes vague or nonexistent. Labels often recommend product application on an "as-needed" basis for control of vegetation. Specific information, such as plant growth stage for applications, timing of repeat applications, and product formulations (i.e., g ai/L), are commonly missing.

BurnOut $^{\circledR}$, Bioganic $^{\circledR}$, and Organic Interceptor ${ }^{\circledR}$ are commercially available products that are composed of a wide range of natural formulations. Except for BurnOut ${ }^{\circledR}$ or other acetic acid formulations, the U.S. Environmental Protection Agency (EPA) has classified these products as minimum risk pesticides and has exempted them from EPA registration requirements determined by the Administrator, under section 25(b) of Federal Insecticide, Fungicide and Rodenticide Act (FIFRA) (EPA 2002). The active ingredients, which can be found on the 25(b) list, have been determined "to be of a character which is unnecessary to be subject to this Act [FIFRA]" alone or in combination with other exempt substances (EPA 2002). Acetic acid is a permitted inert ingredient only when used with products from the 25(b) list, otherwise it is not exempt.

The active ingredient in BurnOut ${ }^{\circledR 5}$ is acetic acid. Research on aquatic weed species, Hydrilla verticillata in particular, has shown a 50\% reduction in growth with dilute concentrations ( 9 to $26 \mathrm{mmol} / \mathrm{L}$ ) of acetic acid (Spencer and Ksander 1995). In terrestrial applications, it was found that a $5 \%$ concentration of acetic acid applied once at $187 \mathrm{~L} / \mathrm{ha}$ and a second time at $374 \mathrm{~L} / \mathrm{ha}$ provided good burn down of field bindweed (Convolvulus arvensis L.), but regrowth was rapid (W. T. Lanini, unpublished data). In another study, herbaceous weeds

\footnotetext{
${ }^{4}$ Bioganic, EcoSMART Technologies, Inc., 318 Seaboard Lane, Suite 202, Franklin, TN 37067.

${ }^{5}$ BurnOut, St. Gabriel Laboratories, 14540 John Marshall Highway, Gainesville, VA 20155.
}

were hand sprayed with various solutions of vinegar (acetic acid), and concentrations of less than 10\% killed the weeds during their first 2 wk of life (Radhakrishnan et al. 2002). Older plants required higher concentrations of vinegar to kill them, and the higher concentrations had a kill rate of greater than $85 \%$ for all growth stages. Similar concentrations did not control yellow starthistle seedlings (J. M. DiTomaso, unpublished data).

Bioganic ${ }^{\circledR}$ is a blend of active ingredients consisting of plant essential oils. These oils have been defined as natural plant products that accumulate in specialized structures such as oil cells, glandular trichomes, and oil or resin ducts (Simon 1997). In addition to its status as a minimum risk pesticide, the active ingredients also are approved as direct food additives or generally recognized as safe by the U. S. Food and Drug Administration.

Organic Interceptor ${ }^{\circledR 6}$ is composed of pine oil extracts. Limited scientific data exist on the use of this product for vegetation control. For pest management in the United States, pine oil has been used primarily for controlling insects (O’Donnell 1986; Werner 1986).

A synthetic or nonsynthetic chemical must have a high level of efficacy to be acceptable for maintaining or controlling vegetation. Using a chemical that does not consistently control vegetation is uneconomical in terms of both time and money. This is true for all weed control methods, including cultural, biological, and mechanical methods. There is a need for more scientific testing of natural products to determine both the specific level of control and the cost to the applicator and the environment, monetarily and toxicologically, respectively. The objectives of this study were to determine the efficacy and costs of natural products compared with a synthetic herbicide for roadside vegetation control. Assessing the environmental effects from the natural products was beyond the capabilities and funding of this research.

\section{MATERIALS AND METHODS}

Studies were established along Hopland Research and Extension Center (HREC) and California State Route 29 (SR29) roadsides in 2001 and 2002, respectively. HREC and SR29 lie 60 to $80 \mathrm{~km}$ inland from the Pacific Ocean and experience a typical Mediterranean climate of hot, dry summers and cool, wet winters. Soil type along the roadside location at HREC and SR29 was Pinole (fineloamy, mixed, thermic Ultic Argixerolls) and Manzanita (fine-loamy, mixed, thermic Ultic Palexeralfs), respec-

\footnotetext{
${ }^{6}$ Organic Interceptor, Organic Interceptor Products Ltd., 102 Sealey Street, P.O. Box 272, Thames, Coromandel Peninsula, New Zealand.
} 
Table 1. Environmental conditions and weed growth stages when POST herbicides were applied at HREC in 2001. ${ }^{\mathrm{a}}$

\begin{tabular}{lcc}
\hline Application parameters & April 11 & April 25 \\
\hline Application timing & POST & $14 \mathrm{~d}$ \\
Air temperature (C) & 21 & 27 \\
Relative humidity (\%) & 47 & 78 \\
Growth stage & & \\
Broadstem filaree & $15 \mathrm{~cm}$; flowering & \\
Foxtail fescue & $13 \mathrm{~cm}$; four leaves & \\
Hare barley & $20 \mathrm{~cm}$; four leaves & \\
Medusahead & $10 \mathrm{~cm}$; four leaves & \\
Ripgut brome & $20 \mathrm{~cm}$; six leaves & \\
Slender oat & $20 \mathrm{~cm}$; six leaves & \\
Soft chess & $18 \mathrm{~cm}$; four leaves & \\
\hline
\end{tabular}

a Abbreviations: HREC, Hopland Research and Extension Center; POST, postemergence.

${ }^{\mathrm{b}}$ Application date.

tively. Annual grasses, principally foxtail fescue [Vulpia myuros (L.) K.C. Gmel. \# FESME], hare barley, medusahead, ripgut brome (Bromus diandrus Roth \# BRODI), slender oat, and soft chess, dominated the sites in both years. In addition, broadleaf filaree at HREC and SR29 and yellow starthistle and buckhorn plantain at SR29 were the most common forbs. The experimental design was a randomized complete block. Plots were 3 by $9 \mathrm{~m}$, and all treatments were replicated four times.

For natural products, applications were made during the warmer daytime hours because of the potential increase in efficacy from burning of plant foliage. The initial concentrations of the commercial formulations of acetic acid, pine oil, and plant essentials were selected based on greenhouse dose-response studies conducted at HREC (S. L. Young, unpublished data) and the limited information from natural product labels. Repeat applications were based on weekly evaluations of plant regrowth and visual control ratings. Some concentrations of the natural products were increased during each experiment to try to improve control because plants or plant tissue that survived each application appeared to become more tolerant. At HREC in 2001, a miscalculation led to an exceedingly high initial application rate of acetic acid $(9 \%, \mathrm{v} / \mathrm{v})$.

All applications were made with a $\mathrm{CO}_{2}$-pressurized backpack sprayer delivering 1,076 L/ha (HREC in 2001) and $935 \mathrm{~L} / \mathrm{ha}$ (HREC and SR29 in 2002) at $248 \mathrm{kPa}$ through $80^{\circ}$ flat-fan tips. ${ }^{7}$ Three nozzles were evenly spaced across a $1.5-\mathrm{m}$ boom. The high spray volume was used to achieve complete coverage of the target vegetation, which is required for natural products. Missed leaves or stems quickly regrow without adequate coverage (Neal 1998).

At HREC in 2001, the treatments of $9 \%(\mathrm{v} / \mathrm{v})$ acetic acid, $58 \mathrm{~kg}$ ai/ha pine oil, and $0.86 \mathrm{~kg}$ ae/ha glyphosate were broadcast applied in a volume of $1,076 \mathrm{~L} / \mathrm{ha}$ on April 11 (Table 1). A sequential application of $1 \%$ acetic acid and $72 \mathrm{~kg} / \mathrm{ha}$ pine oil was made on April 25. Weed control for each species was visually evaluated approximately $1 \mathrm{wk}$ after application and rated on a scale of 0 (no control) to $100 \%$ (plant death) as compared with the nontreated control. The ANOVA was conducted using the general linear models procedure. All efficacy data were separated by LSD at $\mathrm{P}<0.05$.

At HREC in 2002, broadcast treatments of $2 \%$ acetic acid, $10 \%$ plant essentials, $63 \mathrm{~kg} / \mathrm{ha}$ pine oil, and 0.56 $\mathrm{kg} / \mathrm{ha}$ glyphosate were applied in a volume of $935 \mathrm{~L} / \mathrm{ha}$ on February 26 (Table 2). Sequential applications of 3, 6 , and $6 \%$ acetic acid, 15,25 , and $25 \%$ plant essentials, and 94,157 , and $157 \mathrm{~kg} / \mathrm{ha}$ pine oil were made periodically depending on vegetative growth, beginning on March 27 (Table 2). A second application of glyphosate at $0.56 \mathrm{~kg} / \mathrm{ha}$ was made on May 15 . Control of slender oat and scarlet pimpernel (Anagallis arvensis L. \# AN-

${ }^{7}$ XR TeeJet extended range flat spray tips XR 8002, Spraying Systems Co., North Avenue, Wheaton, IL 60188.

Table 2. Environmental conditions and weed growth stages when POST herbicides were applied at HREC in $2002 .{ }^{a}$

\begin{tabular}{|c|c|c|c|c|}
\hline Application parameters & February $26^{\mathrm{b}}$ & March 27 & April 18 & May 15 \\
\hline Application timing & POST & $30 \mathrm{~d}$ & $52 \mathrm{~d}$ & $79 \mathrm{~d}$ \\
\hline Air temperature $(\mathrm{C})$ & 26 & 23 & 21 & 26 \\
\hline Relative humidity (\%) & 31 & 43 & 75 & 32 \\
\hline \multicolumn{5}{|l|}{ Growth stage } \\
\hline Slender oat & $<15 \mathrm{~cm}$; five leaves & & & \\
\hline Scarlet pimpernel & - & - & $<15 \mathrm{~cm}$; four leaflets & \\
\hline Soft chess & $<10 \mathrm{~cm}$; four leaves & & & \\
\hline Hare barley & - & $<10 \mathrm{~cm}$; four leaves & & \\
\hline Broadleaf filaree & $<10 \mathrm{~cm}$; eight leaves & & & \\
\hline Turkey mullein & - & - & $<13 \mathrm{~cm}$; eight leaves & \\
\hline Medusahead & - & - & $<10 \mathrm{~cm} ;$ four leaves & \\
\hline
\end{tabular}

a Abbreviations: HREC, Hopland Research and Extension Center; POST, postemergence.

${ }^{\mathrm{b}}$ Application date. 
Table 3. Environmental conditions and weed growth stages when POST herbicides were applied at SR29 in 2002. ${ }^{a}$

\begin{tabular}{|c|c|c|c|c|c|}
\hline Application parameters & February $25^{\mathrm{b}}$ & March 26 & April 25 & May 16 & June 7 \\
\hline Application timing & POST & $28 \mathrm{~d}$ & $59 \mathrm{~d}$ & $80 \mathrm{~d}$ & $102 \mathrm{~d}$ \\
\hline Air temperature $(\mathrm{C})$ & 23 & 20 & 23 & 27 & 26 \\
\hline Relative humidity (\%) & 33 & 32 & 54 & 35 & 43 \\
\hline \multicolumn{6}{|l|}{ Growth stage } \\
\hline Broadleaf filaree & $13 \mathrm{~cm}$; five leaves & & & & \\
\hline Buckhorn plantain & $13 \mathrm{~cm}$; eight leaves & & & & \\
\hline Curly dock & $20 \mathrm{~cm}$; three leaves & & & & \\
\hline Foxtail fescue & $15 \mathrm{~cm}$; six leaves & & & & \\
\hline Hairy vetch & $15 \mathrm{~cm}$; five leaflets & & & & \\
\hline Hare barley & $15 \mathrm{~cm}$; six leaves & & & & \\
\hline Medusahead & - & & $15 \mathrm{~cm}$; four leaves & & \\
\hline Slender oat & $20 \mathrm{~cm}$; six leaves & & & & \\
\hline Soft chess & $10 \mathrm{~cm}$; six leaves & & & & \\
\hline Yellow starthistle & $20 \mathrm{~cm}$; eight leaves & & & & \\
\hline
\end{tabular}

a Abbreviations: POST, postemergence; SR29, California State Route 29.

${ }^{\mathrm{b}}$ Application date.

GAR) was evaluated visually four times, starting on March 8 and ending on May 24. Before drought-induced senescence of early-winter annuals, control of soft chess, hare barley, and broadleaf filaree was evaluated three times, starting on March 8. Control of turkey mullein [Eremocarpus setigerus (Hook.) Benth. \# ERMSE] and medusahead was evaluated on April 25 and May 24.

At SR29 in 2002, treatments of 5\% acetic acid, $15 \%$ plant essentials, $125 \mathrm{~kg} / \mathrm{ha}$ pine oil, and $0.75 \mathrm{~kg} / \mathrm{ha}$ glyphosate were applied similarly as at HREC in 2002. Depending on vegetative growth, sequential applications of $5,5,6$, and $7 \%$ acetic acid, 15, 15, 20, and 30\% plant essentials, and 125, 125, 150, and $188 \mathrm{~kg} / \mathrm{ha}$ pine oil were made, starting on March 26 (Table 3). Glyphosate was applied a second time at $0.56 \mathrm{~kg} / \mathrm{ha}$ on May 16 . Control of yellow starthistle, slender oat, hairy vetch, foxtail fescue, curly dock (Rumex crispus L. \# RUMCR), and buckhorn plantain was evaluated, beginning on March 5 and ending June 14. Because of emergence and senescence patterns of weed species during the growing season, control of broadleaf filaree, hare barley, and soft chess was evaluated early in the season between March 5 and May 1. Control of medusahead was evaluated later in the season between May 1 and June 14 .

The treatment cost for each application was calculated by multiplying the product price by the rate and addition of the application fee. Total treatment costs were determined by summing the costs of all applications. Calculations were based on 2001 to 2002 herbicide and California Department of Transportation roadside herbicide application costs.

\section{RESULTS AND DISCUSSION}

Weed Control. All treated vegetation showed some degree of phytotoxicity from the natural products. Because of the warm, dry spring at HREC in 2001, soft chess, ripgut brome, foxtail fescue, and broadleaf filaree senesced before the second application of the natural products and could not be included in this evaluation.

Acetic acid and glyphosate controlled all weed species at least 79 and $99 \%$, respectively, after the initial appli-

Table 4. Weed control with natural products and glyphosate along a roadside at HREC in 2001.a

\begin{tabular}{|c|c|c|c|c|c|c|c|c|}
\hline \multirow[b]{3}{*}{ Treatment } & \multirow[b]{3}{*}{ Rate $^{\mathrm{b}}$} & \multirow[b]{3}{*}{ Timing } & \multicolumn{6}{|c|}{ Weed control ${ }^{\mathrm{c}}$} \\
\hline & & & \multicolumn{2}{|c|}{ AVEBA } & \multicolumn{2}{|c|}{ ELYCM } & \multicolumn{2}{|c|}{ HORLE } \\
\hline & & & $7 \mathrm{~d}$ & $21 \mathrm{~d}$ & $7 d$ & $21 \mathrm{~d}$ & $7 d$ & $21 \mathrm{~d}$ \\
\hline Acetic acid & $9+1 \%(\mathrm{v} / \mathrm{v})$ & POST $+14 d$ & $79 \mathrm{~b}$ & $58 \mathrm{~b}$ & $95 \mathrm{a}$ & $73 \mathrm{~b}$ & $89 \mathrm{~b}$ & $35 \mathrm{~b}$ \\
\hline Glyphosate & $0.86 \mathrm{~kg}$ ae $/ \mathrm{ha}$ & POST & $99 \mathrm{a}$ & $100 \mathrm{a}$ & $100 \mathrm{a}$ & $100 \mathrm{a}$ & $100 \mathrm{a}$ & $100 \mathrm{a}$ \\
\hline Pine oil & $58+72 \mathrm{~kg} \mathrm{ai} / \mathrm{ha}$ & POST $+14 d$ & $19 \mathrm{c}$ & $31 \mathrm{c}$ & $40 \mathrm{~b}$ & $63 \mathrm{~b}$ & $15 \mathrm{c}$ & $24 \mathrm{~b}$ \\
\hline Control & & & $0 \mathrm{~d}$ & $0 \mathrm{~d}$ & $0 \mathrm{c}$ & $0 \mathrm{c}$ & $0 \mathrm{~d}$ & $0 \mathrm{c}$ \\
\hline
\end{tabular}

a Abbreviations: HREC, Hopland Research and Extension Center; POST, Postemergence.

${ }^{\mathrm{b}}$ All treatments were applied in 1,076 L/ha spray volume.

${ }^{c}$ Weed species codes within a column are slender oat (AVEBA), medusahead (ELYCM), and hare barley (HORLE). Values followed by a different letter are significantly different at $\mathrm{P}=0.05$. 
YOUNG: NATURAL PRODUCT HERBICIDES FOR CONTROL OF ANNUAL VEGETATION
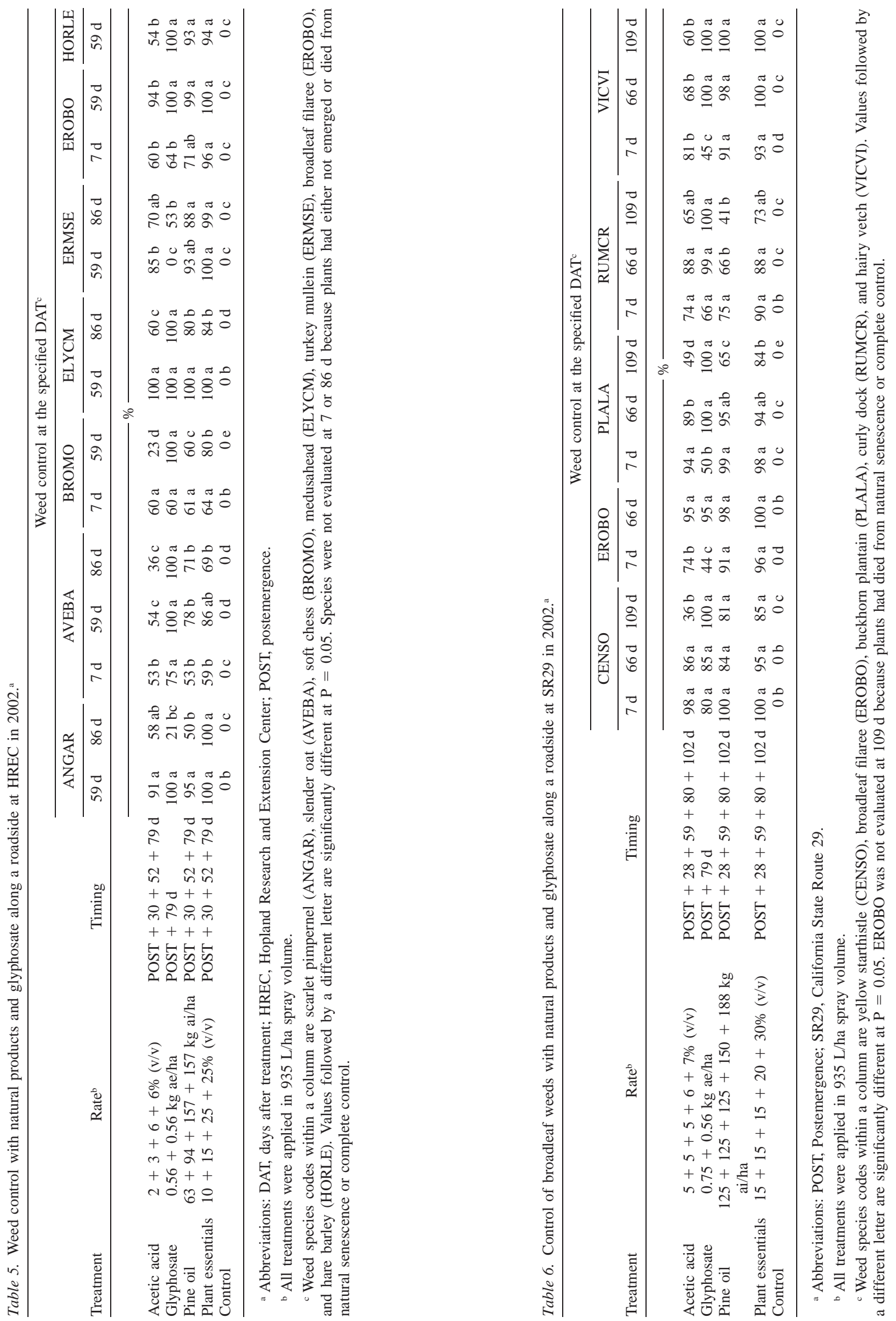


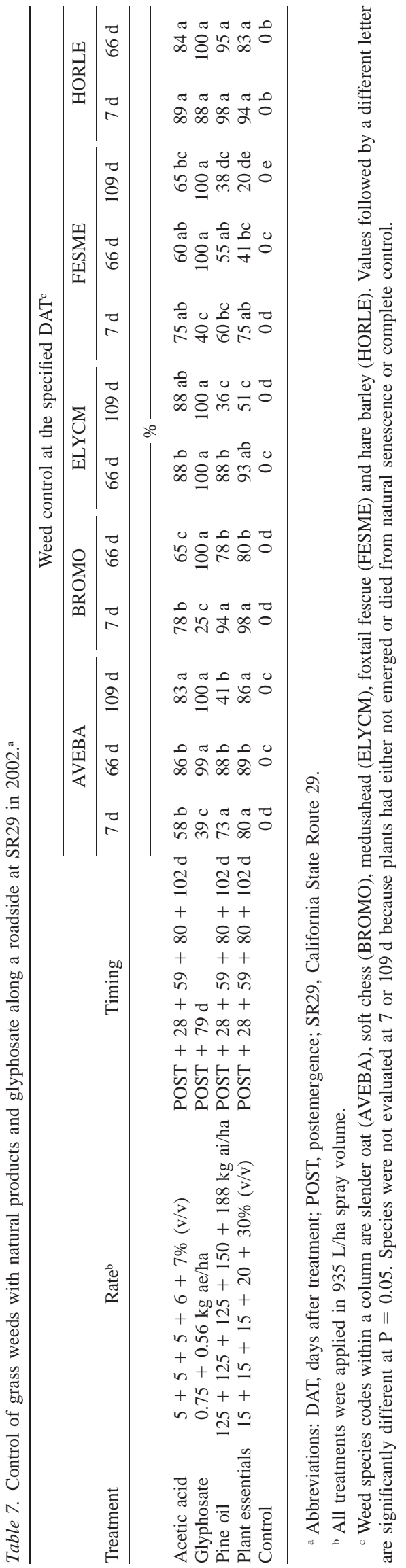

cation (Table 4). Slender oat and hare barley control declined to 58 and $35 \%$, respectively, for acetic acid even after a second application on April 25. The reason for the sharp decline in control with acetic acid is unknown, but weather conditions and a lower second application rate than what was planned were probably key factors. Regardless, control was not maintained and may still have been low despite using a higher rate, which later proved to be true in studies at HREC and SR29 in 2002. In the plots treated with glyphosate, control was $100 \%$ with only a single application. Initial weed control with pine oil was $40 \%$ or less, but medusahead control improved after a second application. This was probably due to the younger growth stage of medusahead resulting from later shoot growth and development when compared with the other annual grass weed species (Kan and Pollak 2000). All the natural products were less than satisfactory in the level of control after a second application $(<73 \%)$ and significantly less than the standard treatment of glyphosate.

Similar to 2001, another warm, dry spring at HREC in 2002 resulted in early senescence of any remaining plants of broadleaf filaree, soft chess, and hare barley after the third application of the natural products, and these were not included in a fourth evaluation. After three applications of acetic acid, control of broadleaf filaree, scarlet pimpernel, and turkey mullein was $85 \%$ or greater (Table 5). Acetic acid did not adequately control any of the grass weeds, except for the 52-d application on medusahead (100\%). A second application at the same rate $25 \mathrm{~d}$ later resulted in only $60 \%$ control, indicating the possible need for shorter intervals between repeat applications. Pine oil and plant essentials were more effective than acetic acid for control of hare barley and medusahead at 94 and 84\%, respectively, at their final ratings. After four applications, pine oil and plant essentials showed similar control of slender oat at 71 and $69 \%$, respectively, which was still significantly lower than two applications of glyphosate (100\%). One application of glyphosate controlled all vegetation at $59 \mathrm{~d}$ after treatment (DAT), except for the late-emerging turkey mullein. Although turkey mullein and scarlet pimpernel were not controlled after a second application of glyphosate at $0.56 \mathrm{~kg} / \mathrm{ha}$, control eventually reached $100 \%$ (data not shown).

At SR29 in 2002, acetic acid provided $83 \%$ or better control of broadleaf filaree and hare barley after three applications and slender oat and medusahead after five applications (Tables 6 and 7). Control of yellow starthistle after one application was $98 \%$, but after five ap- 
Table 8. Material and application cost of natural products and glyphosate along a roadside at HREC in 2001 and HREC and SR29 in $2002 .{ }^{a}$

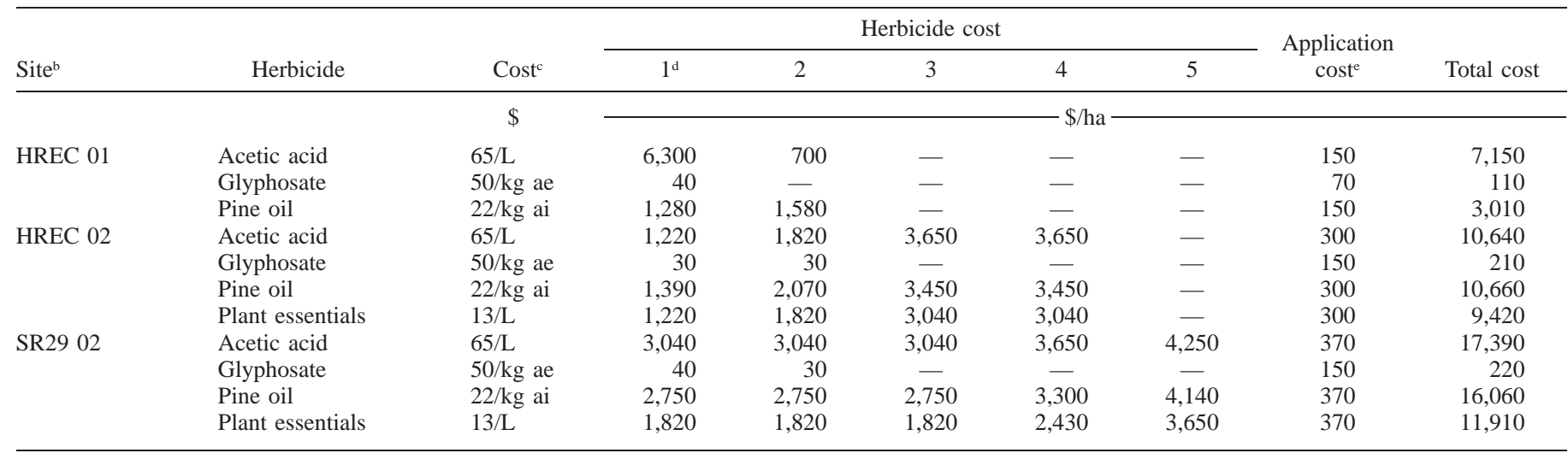

a Abbreviations: HREC, Hopland Research and Extension Center; SR 29, California State Route 29.

${ }^{\text {b }}$ HREC 2001 treatments applied in 1,076 L/ha spray volume. HREC 2002 and SR 29 treatments applied in 935 L/ha spray volume.

${ }^{c}$ Acetic acid and plant essentials costs are based on the equivalent of $100 \%$ concentrations.

d Application number.

e Based on California Department of Transportation, District 1, cost to make roadside application of herbicides.

plications, control dropped to $36 \%$. Similar trends were observed for the control of hairy vetch, soft chess, and buckhorn plantain. Plant essentials and pine oil controlled vetch, broadleaf filaree, and hare barley at least $83 \%$. The two products also provided good control $(>88 \%)$ of yellow starthistle, soft chess, buckhorn plantain, and medusahead after one application but subsequently declined in control $(<85 \%)$ by the last application 109 DAT. Yellow starthistle was the only weed that one application of glyphosate did not control ( $>95 \%)$ up to 66 DAT. A second application provided $100 \%$ control of yellow starthistle and any other vegetation 109 DAT. A consistent level of control with the natural products compared with the standard treatment of glyphosate was not achieved for seven (yellow starthistle, slender oat, soft chess, buckhorn plantain, foxtail fescue, curly dock, and medusahead) of the 10 weed species evaluated.

Treatments were consistent in their level of control of target weed species in 2001 and 2002 at both locations. The low level of control with the natural products at HREC in 2001 continued at HREC and SR29 in 2002. Increased rates and numbers of applications of the natural products did little to equal the efficacy that was achieved with glyphosate. Vegetation control remained at a lower level for the natural products, even with earlier and timelier applications in 2002.

Weed Control Costs. Out of the natural products, only acetic acid costs more than the synthetic herbicide on a per product basis (Table 8). The cost on a per hectare basis was substantially higher for the natural products when based on the volume of the formulated product (data not shown). However, this difference was even more substantial when application costs were included. Glyphosate was the most economical on a per hectare basis because it required only one or two low rate applications for desirable vegetation control. At HREC in 2001, the cost of acetic acid, one of the more commonly known natural products, was $\$ 700 /$ ha for a second and lowest rate $(1 \%, \mathrm{v} / \mathrm{v})$ application for all natural products. The cost of glyphosate was five times less at $\$ 120 /$ ha for only a single application that provided a higher level of control.

Similar to HREC in 2001, multiple applications at HREC in 2002 increased the cost for use of the natural products dramatically. Including applicator costs, four applications of plant essential oils, acetic acid, and pine oil cost from $\$ 9,420 /$ ha to $\$ 10,660 /$ ha. Two applications of glyphosate cost $\$ 210 / \mathrm{ha}$. The high number of repeat applications was the major factor in raising the overall cost to use the natural products. At SR29, five applications of acetic acid, pine oil, and plant essentials cost greater than $\$ 11,910 /$ ha, whereas two applications of glyphosate cost $\$ 220 / \mathrm{ha}$. None of the natural products were deemed economically feasible for use in controlling herbaceous roadside vegetation.

There may be several factors for the poor performance of the natural products in controlling roadside vegetation in this study. First, the fact that natural products have little or no systemic activity and appeared to be the major cause of poor control has been documented in these studies. Second, as the growth stage of the vegetation progresses and the surface area of the plant enlarges, the effectiveness of natural products decreases rapidly be- 
cause more area has to be covered for control to be achieved. Third, to obtain proper spray coverage of and contact with the target vegetation using natural products, several vegetation control methods are needed. Cultivating or mowing before an application would help to remove the excess debris and plant matter that may inhibit adequate contact. The necessity for repeat applications of natural products increases the likelihood of hindrance of control by dead and decaying plant material from previous applications. Finally, natural products are simply not as efficacious as the synthetic herbicide glyphosate.

At this stage of research, natural products lack the same chemical capacity as many synthetic products to control vegetation, even with high-volume applications, debris-free application sites, and precision application timing. Continued research is warranted in laboratory and field studies to develop methods of increasing natural product efficacy.

\section{LITERATURE CITED}

Bingaman, B. R. and N. E. Christians. 1995. Greenhouse screening of corn gluten meal as a natural control product for broadleaf and grass weeds. Hortscience 30:1256-1259.
Bingaman, B. R., M. J. Howieson, and N. E. Christians. 2000. Alldown natural herbicide study. Turfgrass Research Report. Iowa State University, Ames, IA.

[EPA] Environmental Protection Agency. 2002. Pesticide Registration and Classification Procedures. Title 40, Code of Federal Regulations. Section 152.25 (f). Washington, DC: Office of the Federal Register National Archives and Records Administration. U.S. Government Printing Office.

Kan, T. and O. Pollak. 2000. Taeniatherum caput-medusae. In C. C. Bossard, J. M. Randall, and M. C. Hoshovsky, eds. Invasive Plants of California's Wildlands. Santa Rosa, CA: University of California Press. Pp. 309-312.

Neal, J. C. 1998. Postemergence, Non-selective Herbicides for Landscapes and Nurseries. Horticulture Information Leaflets. Raleigh, NC: North Carolina State University. 4 p.

O'Donnell, B. P. 1986. Effect of pine oil on landing and attack by the southern pine beetle (Coleoptera: Scolytidae). J. Entomol. Sci. 21:319-321.

Radhakrishnan, J., J. R. Teasdale, and B. Coffman. 2002. Spray weeds with vinegar? USDA-ARS News Brief 5/15/02. Web page: http:// www.ars.usda.gov/is/pr/2002/020515.htm Accessed: April 23, 2004.

Simon, J. E. 1997. New crop introduction: exploration, research and commercialization of aromatic plants in the new world. In Proceedings of the Prairie Medicinal and Aromatic Plants Conference. Brandon, MB, Canada: Western Economic Diversification Canada. 131 p.

Spencer, D. F. and G. G. Ksander. 1995. Influence of acetic acid on regrowth of dioecious hydrilla from root crowns. J. Aquat. Plant Manag. 33:61-63.

Vurro, M. and J. Gressel. 2001. Enhancing biocontrol agents and handling risks. NATO Advanced Research Workshop on Enhancing Biocontrol Agents and Handling Risks. Florence, Italy. Amsterdam. Washington, DC: IOS.

Werner, R. A. 1986. Evaluation of pine oil for protecting white spruce from spruce beetle (Coleoptera: Scolytidae) attack. J. Entomol. Soc. B. C. 83:3-5. 